\title{
Evaluation of Varying Doses of Pergonal on Seminal, Haematology and Serum Minerals of Adult Rabbits
}

\author{
ONYEKWERE, Moses Ukoha, *JIWUBA, Peter-Damian Chukwunomso, \\ ONWUJIARIRI, Ebere Bede
}

Department of Animal Production, Federal College of Agriculture, P.M.B.7008, Ishiagu, Ebonyi State, Nigeria.

*Corresponding Author: JIWUBA, Peter-Damian Chukwunomso, Department of Animal Production, Federal College of Agriculture, P.M.B.7008, Ishiagu, Ebonyi State, Nigeria.

\begin{abstract}
The responses of 24 adult male rabbits treated with different doses of pergonal on seminal, haematology and electrolyte indices were studied for 84 days. The rabbits were divided into three experimental groups of eight rabbits and replicated twice with four rabbits constituting a replicate in a completely randomized design. A vial of pergonal was dissolved in $1 \mathrm{ml}$ of saline and assigned to each experimental designated as $T_{1}(0.0 \mathrm{ml}), T_{2}(6.0 \mathrm{i} \mu)$ and $T_{3}(12.0 \mathrm{i} \mu)$. Data on seminal, haematology and electrolytes indices were collected and evaluated. The result revealed that apart from semen volume, all the seminal indices evaluated showed significant $(p<0.05)$ difference. PCV and MCV were also significant ( $p<0.05)$. PCV tended to be better and higher for the control group. However, all serum minerals studied were significantly $(p<0.05)$ influenced by the pergonal doses. From the results of this study, it was concluded that, on the account of fertility, blood formation and serum electrolyte, pergonal could be used to enhance rabbit production. This experiment revealed that 6.00 i $\mu$ doses of pergonal should be recommended for enhanced haematological and seminal indices, while 12.0iu pergonal doses for better electrolytes indices.
\end{abstract}

Keywords: Rabbit, semen characteristics, blood profile, fertility drugs and mini-livestock.

\section{INTRODUCTION}

Genetic variation is one of the main objective tools traditionally used for animal improvement scheme. It allows farmers to select or develop new breeds [1] in response to changes in the environment, diseases, nutritional requirement and market condition. Animal genetics is critical for achieving food security for the rapidly growing population. In recent years, advances in the field of biotechnology have opened up a completely new area of molecular levels with the introduction of techniques such as fertility drug employed to improve animal performance. Some drugs have been documented for their possibility in stimulation of spermatogenesis.

Fertility drugs have been seen as a possible means of improving sperm count and motility. [2]investigated the use of fertility drug in the induction of spermatogenesis in male rabbits and reported positive reports. [3] however noted that bucks produce semen with very low sperm counts. Thus, attempts to stimulate sperm production using easily available preparations with the aim of ensuring high, sperm counts, libido and invariably high conception rate in inseminated does cannot be over emphasized.

Pergonal acts in males and females by stimulating the production of pituitary gonadotrophins possibly through the stimulation of the secretion of gonadotrophin releasing hormone $(\mathrm{GnRH})$ by hypothalamus. [4]studied the effect of hormonal administration on blood parameters of West African Dwarf Goat. However, there is paucity of information on the effect of pergonal administration on rabbits. Therefore, this experiment was conducted to determine the effect of pergonal on seminal, haematology and electrolyte indices of rabbits.

\section{Materials AND Methods}

The experiment was carried out at the teaching and Research Rabbit Farm, Federal College of Agriculture Ishiagu, Ebonyi State. Twenty four New Zealand white rabbit bucks weighing between $3000 \mathrm{~g}$ to $4000 \mathrm{~g}$. The rabbits were divided into three (3) groups of eight (8) rabbit each. Each group 
was further sub-divided into two replicates of four mature rabbits in a completely randomized design. The content of a vial of pergonal was dissolved in $1 \mathrm{ml}$ physiological saline which was assigned to each group of pergonal treatment as $0.0 \mathrm{ml}$ control, $6.0 \mathrm{i} \mu$ and $12.0 \mathrm{i} \mu$. The different doses of pergonal were administered intramuscularly for three consecutive days for upwards of three weeks.

They were dewormed using kepromec (Ivermectin) at the rate of $0.1 \mathrm{ml}$ per rabbit subcutaneously and given accaricide bath using Roys'Amitraz 20 at the rate of $1 \mathrm{ml}$ in 2 litre water prior to the experiment and feed $a d$ libitum with concentrate and forage. Clean fresh water was provided daily and liberally. Daily cleaning of pens and health management measures of the rabbit for defect were carried out. In addition, other management practices were clearly observed to give an enabling environment for the optimum performance of the rabbit.

Blood samples were collected two times at intervals of $6^{\text {th }}$ and $12^{\text {th }}$ week of the trial. Seven millimeter of blood was aspirated from each rabbit. Two millimeter of each sample was discarded into Ethylene diamine Tetra Acetic acid (EDTA) treated biju bottles for haematological studies. The remains of $5 \mathrm{ml}$ of each blood sample were allowed to coagulate to produce sera for seminal and electrolyte measurement. Bleeding was done between $7 \mathrm{am}$ to $8 \mathrm{am}$ on the day of collection.

Blood samples collected from the males were analyzed within three (3) hours of their collection. Packed Cell Volume (PVC) and haemaglobin Concentration were determined according to the methods described by [5]. The various Mean Corpuscular Volume (MCV) and Mean Corpuscular Haemoglobin Concentration (MCHC) were calculated from the result obtained from $\mathrm{PCV}, \mathrm{Hb}$ and RBC. Haemoglobin Concentration $(\mathrm{Hb})$ and red blood cell (RBC) were determined using Wintrobesmicrohaematocrit and improved Neubauerhaemocytometer, respectively [6].

The coagulated blood samples were subjected to standard method of seminal separation, the harvested sera were used for evaluation of seminal and electrolyte levels using ELISA kit technique as described by [7]. The standard flame photometry using Gallenkamp analysis were used to determine serum sodium $\left(\mathrm{Na}^{+}\right)$ion, Calcium $\left(\mathrm{Ca}^{+}\right)$, Potassium $\left(\mathrm{K}^{+}\right)$ion. Bicarbonate and Chloride ion will be determined according to the method of [8].

All data collected from this trail were subjected to analysis of variance [9]. While significant means were separated using Duncan New multiple range test as outlined by [10].

\section{RESUlts}

The seminal characteristics of the rabbits given pergonal doses are presented in Table 1. The semen volume did not show any significant $(\mathrm{P}>0.05)$ difference among different doses administered. Sperm motility, semen concentration, total sperm and abnormal sperm proportion showed significant $(\mathrm{P}<0.05)$ difference across the treatment groups.The haematological profile of rabbit administered different doses of pergonal is presented in Table 2 . There were significant differences $(\mathrm{P}<0.05)$ for PCV and MCV, while other haematological parameters examined were similar ( $>0.05)$ across the treatments. Packed cell volume (PCV) showed a particular trend, decreasing with increasing levels of pergonal, with T1 having highest value of $38.30 \%$ with a corresponding lowest value of $33.15 \%$ on T3 animals. Table 3 indicated the electrolyte of rabbit treated different doses of pergonal. All the serum minerals examined were significantly $(\mathrm{p}<0.05)$ influenced by the pergonal doses.

Table 1. Seminal characteristics of adult rabbits administered varying doses of pergonal

\begin{tabular}{|l|l|l|l|l|}
\hline & & Treatment levels & & \\
\hline Parameters & $\mathbf{0 . 0}($ saline$)$ & $\mathbf{6 . 0 0} \mathbf{i} \boldsymbol{\mu}$ & $\mathbf{1 2 . 0 0} \mathbf{i} \boldsymbol{\mu}$ & SEM \\
\hline Semen volume $(\mathrm{ml})$ & 0.54 & 0.57 & 0.56 & 0.00 \\
\hline Sperm motility $(\%)$ & $56.12^{\mathrm{c}}$ & $60.10^{\mathrm{a}}$ & $59.75^{\mathrm{b}}$ & 1.27 \\
\hline Sperm Concentration $\left(\mathrm{x} 10^{6} \mathrm{ml}\right)$ & $72.86^{\mathrm{c}}$ & $75.00^{\mathrm{a}}$ & $54.25^{\mathrm{a}}$ & 3.50 \\
\hline Total sperm $\left(\mathrm{x} 10^{6} / \mathrm{ml}\right)$ & $35.25^{\mathrm{c}}$ & $56.00^{\mathrm{a}}$ & $40.40^{\mathrm{b}}$ & 5.99 \\
\hline Abnormal sperm proportion $(\%)$ & $12.55^{\mathrm{c}}$ & $13.25^{\mathrm{b}}$ & $13.30^{\mathrm{a}}$ & 0.24 \\
\hline
\end{tabular}

${ }_{\mathrm{a}, \mathrm{b}, \mathrm{c}}$ means within row with the same superscript are not significantly $(\mathrm{p}>0.05)$ different

Table 2. Effects of pergonal doses on haematology of adult rabbits.

\begin{tabular}{|l|l|l|l|l|}
\hline Parameters & $\mathbf{0 . 0}($ saline $)$ & $\mathbf{6 . 0 0} \mathbf{i} \boldsymbol{\mu}$ & $\mathbf{1 2 . 0 0} \mathbf{i} \boldsymbol{\mu}$ & SEM \\
\hline Packed cell volume $(\%)$ & $38.30^{\mathrm{a}}$ & $35.33^{\mathrm{b}}$ & $33.15^{\mathrm{c}}$ & 0.56 \\
\hline Haemoglobin $(\mathrm{g} / \mathrm{d})$ & 10.06 & 10.02 & 9.89 & 0.51 \\
\hline White blood cell $\left(\mathrm{x} 10^{3} / \mu \mathrm{l}\right)$ & 8.20 & 8.82 & 8.84 & 0.38 \\
\hline
\end{tabular}

International Journal of Research Studies in Microbiology and Biotechnology (IJRSMB)

Page | 33 
Evaluation of Varying Doses of Pergonal on Seminal, Haematology and Serum Minerals of Adult Rabbits

\begin{tabular}{|l|l|l|l|l|}
\hline \hline Red blood cell $\left(10^{6} / \mu \mathrm{l}\right)$ & 5.53 & 5.23 & 5.43 & 0.09 \\
\hline Mean cell volume $(\mathrm{pg})$ & 16.23 & 16.45 & 16.80 & 0.17 \\
\hline Mean cell haemoglobin $(\mathrm{fl})$ & $60.50^{\mathrm{b}}$ & $63.20^{\mathrm{a}}$ & $63.02^{\mathrm{a}}$ & 0.54 \\
\hline Mean cell haemoglobin concentration $(\mathrm{g} / \mathrm{d})$ & 32.83 & 32.64 & 32.45 & 0.11 \\
\hline
\end{tabular}

$, a, b, c$ means within row with the same superscript are significantly $(\mathrm{p}<0.05)$ different

Table 3. Effects of pergonal on serum minerals of adult rabbits

\begin{tabular}{|l|l|l|l|l|}
\hline & & Treatment levels & & \\
\hline Parameters & $\mathbf{0 . 0}($ saline$)$ & $\mathbf{6 . 0 0} \mathbf{i} \boldsymbol{\mu}$ & $\mathbf{1 2 . 0 0} \mathbf{i} \boldsymbol{\mu}$ & SEM \\
\hline Calcium $(\mathrm{mg} / \mathrm{dl})$ & $15.60^{\mathrm{a}}$ & $12.61^{\mathrm{c}}$ & $13.35^{\mathrm{b}}$ & 0.90 \\
\hline Phosphorus (md/dl) & $6.35^{\mathrm{b}}$ & $6.45^{\mathrm{a}}$ & $6.45^{\mathrm{a}}$ & 0.03 \\
\hline Sodium (md/dl) & $143.30^{\mathrm{b}}$ & $144.50^{\mathrm{ab}}$ & $148.35^{\mathrm{a}}$ & 1.48 \\
\hline Potassium (mmoi/l) & $4.60^{\mathrm{b}}$ & $5.45^{\mathrm{ab}}$ & $5.60^{\mathrm{a}}$ & 0.31 \\
\hline Chloride (mmoi/l) & $103.40^{\mathrm{c}}$ & $112.00^{\mathrm{b}}$ & $113.00^{\mathrm{a}}$ & 3.05 \\
Bicarbonate (mmoi/l) & $27.20^{\mathrm{c}}$ & $30.45^{\mathrm{b}}$ & $31.30^{\mathrm{a}}$ & 1.25 \\
\hline
\end{tabular}

abc means within row with the same superscript are not significantly $(p>0.05)$ different

\section{DISCUSSION}

The non significance on the semen volume is in agreement with the reports of [11] and [12].This may be attributed to high frequency of ejaculation which affects the quantity of male semen volume. The range of values obtained for semen volume in this present study is within the reported values by [13].Sperm concentration tended to increase with increasing doses of pergonal increased. This may be due to frequency of semen collection which positively affects the production of life and active cells of sperm dispensation that mobilizes the productive factor to initiate libido in the animals. A high concentration of semen results to adequate sperm motility. However, abnormal sperm proportion values increased progressively as different doses were administered while total sperm decreased with increase of doses applied. This may be as a result of the frequency in semen collection which lowers the proportion of live spermatozoa; a view corroborated by [14].

The PCV values recorded in this study is within the normal physiological range of 33.00-50.00\% reported by [15]for apparently healthy rabbits. This suggests absence of anaemia or feed toxicity among the experimental animals; a view corroborated by [16]. The mean corpuscular volume (MCV) could reflect anaemic condition and the capacity of the bone marrow to produce $\mathrm{RBC}$ of normal size and metabolic capacity. The within range of MCV observed in this study gave a clear evidence of absence of anaemia across the treatment groups. The normal range of all the haematological indices evaluated in this study good health condition and adequate blood formation.

Minerals function as body structural components and acid-base balance [17]. The study on electrolyte of rabbits administered pergonal are absolutely necessary for most metabolic processes and also serve as co-factor to help in transmission of nerve impulse and water balance [18].It was observed that potassium at $(0 \%)$ had the lowest values and this may be due to lack of pergonal. In addition potassium values were relatively below the recommended values of $4.6-6.5 \%$ reported by [19]. The similarities in value of phosphorus, sodium, potassium and chloride as observed indicated efficiency of electrolyte balance in the rabbit administered different levels of pergonal. These findings agree with the report of [20]on rabbit having examined the effects of Napolenaimperata as feed ingredients.

\section{CONCLuSion}

The result of this study suggests that the administration of $6.0 \mathrm{i} \mu$ dose of pergonal will improve the sperm production in rabbit without any negative effects on haematology, seminal characteristics and electrolyte of rabbits.

\section{ACKNOWLEDGMENT}

The authors express their gratitude to the Department of Animal Production Technology Federal College of Agriculture, Ishiagu, for their assistance and provision of the experimental animals.

\section{REFERENCES}

[1] P.K. Thornton, Livestock production: recent trends, future prospects. Philos Trans R SocLond B Biol Sci.365(2010)2853-2867.

[2] U. Herbert, A.H. Ezeobi, M.U. Iloeje, Induction of Spermatogenesis in zabbits using the Fertility Drug Clomiphene Citrate (ClomidR). Proc. 27th Ann. Conf. NSAP, Akure, Nigeria. March (2002)17-27. 
[3] F.C. Iheukwumere, A.H. Abu, E.C. Ndubuisi, U.N. Egu, Effect of Clomiphene citrate (clomid®) fertility drug on sperm production rate, gonadal and extragonadal sperm reserves of yankasa rams. International Journal of Natural and Applied Sciences.4 (2008)305-309.

[4] F.C. Iheukwumere, U. Herbert, M.U. Iloeje,Haematological and serum biochemical values of West African Dwarf does following FSH + LH. (Pergonal®) Treatment.Int. J. Agric. Rural Dev. 5 (2001) 54-60.

[5] A.A. Tuffrey, Laboratory animals: In: A.A., Tuffrey (ed), An Introduction for Experiments, John Wilkey and Sons Ltd. England.(1995).

[6] G.N. Lanh, Manual of veterinary laboratory technique: CIBA-GEIGY, Kenya, pp. (1991) 54-55.

[7] M.A. Nowshari, J.F. Beckers, W. Holtz, Superovulation of goats with purifies FSH supplemented with Defined Amounts of PLH. Theriogenology. 43 (1995) 802-808.

[8] F.J. Baker, R.F. Silverton, Introduction to medical laboratory technology: $6^{\text {th }}$ Ed. Butterworth, England.(1995).

[9] R.G.D. Steel, J.H. Torrie, Principles and procedures of statistics: MC Grow- Hill Book Co. New York.(1980).

[10] I.U. Obi, Statistical method of detecting differences between treatment means: $2^{\text {nd }}$ Ed., Snaap Press, Enugu, Nigeria. (1990).

[11] D.O. Umesiobi, M.U. Iloeje, Effects of sexual teasing and diurnal period of semen collection on reaction time and semen characteristics of large white boars. J. Sustain. Agric.And Environs. 21 (1999) 231-235.

[12] D.O. Umesiobi, M.U. Iloeje, G.A. Anyanwu, U. Herbert, N.J. Okeudo, Relationship between spw fecundity and sexual repretoire of the boar. J. Agric. Rural dev. 1(2000)114-119.

[13] H.M. Kabury, H.M. Ibrahim, Relationship between libido and scrotal circumference and each on semen characteristics and fertility in rabbits. Proceeding of International Conference of Animal, Poultry and Rabbit Production and Health, Egyptian Int. Centre for Agric; Dokki, Cairo, Egypt.(1997) 567-575.

[14] F.C. Iheukwumere, U. Herbert, D.O. Umesiobi, Biochemical evaluation of seminal plasma in Yankasa rams under different intensities of semen collection. Int. J. Agric. Rural dev. 2 (2001) 29-34.

[15] J. Burke, Clinical care and medicine of pet rabbit, in: Proceedings of the Michigan Veterinary Conference. (1994) 49-77.

[16] P.C. Jiwuba, K. Ikwunze, E. Dauda, D.O Ugwu, Haematological and serum biochemical indices of growing rabbits fed diets containing varying levels of Moringa oleifera leaf meal. British biotechnology Journal, 15 (2016) 1-7.

[17] M.U. Onyekwere, P.C. Jiwuba, S.O. Okechukwu, A.C. Anuonye, Growth and serum mineral profile of broiler starters fed cocoyam (Colocasiaesculenta) tuber meal. International Journal of Biological Research.4 (2016) 260-262.

[18] A.C. Brown, Chemistry of food composition understanding food properties and preparation: $3^{\text {rd }}$ Ed. Wordsworth Publishing Co. United States. (2007) 46-49.

[19] S.E. Allel, A. Mays, The Merck's Veterinary Manual: $8^{\text {th }}$ ed. Merck and Co. Inc., White House Station.(1999).

[20] F.C. Iheukwumere, I.C. Okoli, Preliminary study on raw Napolenaimperalis as feed ingredients on performance and blood chemistry of weaner rabbits. Tropical Animal Production Investigation.4 (2002) 113-119.

Citation: M. U. ONYEKWERE, et al., “ Evaluation of Varying Doses of Pergonal on Seminal, Haematology and Serum Minerals of Adult Rabbits ", International Journal of Research studies in Microbiology and Biotechnology, vol. 3, no. 4, p. 32-35, 2017. http://dx.doi.org/10.20431/2454-9428.0304005

Copyright: (C) 2017 Authors. This is an open-access article distributed under the terms of the Creative Commons Attribution License, which permits unrestricted use, distribution, and reproduction in any medium, provided the original author and source are credited. 